\title{
Place of food cooking is associated with acute respiratory infection among under- five children in Ethiopia: multilevel analysis of 2005-2016 Ethiopian Demographic Health Survey data
}

Abraham Geremew ${ }^{1 *}$, Selamawit Gebremedhin ${ }^{1}$, Yohannes Mulugeta ${ }^{1}$ and Tesfaye Assebe Yadeta²

\begin{abstract}
Background: Globally, acute respiratory infections are among the leading causes of under-five child mortality, especially in lower-income countries; it is associated with indoor exposure to toxic pollutants from solid biomass fuel. In Ethiopia, $90 \%$ of the population utilizes solid biomass fuel; respiratory illness is a leading health problem. However, there is a paucity of nationally representative data on the association of household cooking place and respiratory infections. Besides, evidence on the variability in the infection based on the data collected at different times is limited. Therefore, this study is intended to assess the association of food cooking place with acute respiratory infections and the variability in households and surveys.

Methods: The current analysis is based on the Ethiopian Demographic and Health Survey data collected in 2005, 2011, and 2016 and obtained via online registration. The association of food cooking place with acute respiratory infection was assessed using multilevel modeling after categorizing all factors into child level and survey level, controlling them in a full model. The analyses accounted for a complex survey design using a Stata command "svy."

Result: A total of 30,895 under-five children were included in this study, of which 3677 (11.9\%) children had an acute respiratory infection, with $12.7 \%$ in $2005,11.9 \%$ in 2011 , and $11.1 \%$ in 2016 . The risk of having an infection in under-five children in households that cooked food outdoors was $44 \%$ lower ( $\mathrm{AOR}=0.56,95 \% \mathrm{Cl}=0.40,0.75$ ) compared to those households that cooked the food inside the house. There was a statistically significant difference among the children among surveys to have an acute respiratory infection.

Conclusion: The risk of having children with acute respiratory infection is lower in the households of cooking food outdoor compared to indoor. The infection difference in different surveys suggests progress in the practices in either food cooking places or the fuel types used that minimize food cooking places location or the fuel types used that minimizes the risk. But, the infection is still high; therefore, measures promoting indoor cooking in a wellventilated environment with alternative energy sources should take place.
\end{abstract}

Keywords: Acute respiratory infection, Food cooking place, Solid biomass fuel

\footnotetext{
* Correspondence: abrahamgeremew2010@gmail.com

'Department of Environmental Health, College of Health and Medical

Sciences, Haramaya University, Dire Dawa, Ethiopia

Full list of author information is available at the end of the article
}

(c) The Author(s). 2020 Open Access This article is licensed under a Creative Commons Attribution 4.0 International License, which permits use, sharing, adaptation, distribution and reproduction in any medium or format, as long as you give appropriate credit to the original author(s) and the source, provide a link to the Creative Commons licence, and indicate if changes were made. The images or other third party material in this article are included in the article's Creative Commons licence, unless indicated otherwise in a credit line to the material. If material is not included in the article's Creative Commons licence and your intended use is not permitted by statutory regulation or exceeds the permitted use, you will need to obtain permission directly from the copyright holder. To view a copy of this licence, visit http://creativecommons.org/licenses/by/4.0/ 


\section{Background}

Acute respiratory infection (ARI) is a leading cause of mortality in children under 5 years old worldwide [1]. About $97 \%$ of ARI cases occur in low- and middleincome countries, with nearly $70 \%$ occurring in South Asia and sub-Saharan Africa [2]. The World Health Organization report in 2015 shows that ARI accounts for $16 \%$ of all deaths globally, killing around one million children under the age of 5 years [3]. In 2017, of nearly 5.4 million under-five children who died worldwide, roughly half were in sub-Saharan Africa, with ARI contributing the highest number of deaths [4]. The recent analysis of the demographic and health survey data (DHS) in sub-Saharan countries shows that the overall prevalence is $25.3 \%$ [5].

Multiple risk factors are associated with ARI including exposure to toxic pollutants in the indoor environment, biomass smoke being one of the most common ones [610]. Smoke from biomass and coal contains a large number of particulate matters of various sizes such as nitrogen dioxide, carbon monoxide, methylene chloride, and dioxins $[7,8,10]$. Women and under-five children are exposed to these pollutants because of the long periods of time spent in close proximity to fires while cooking and heating [11]. Pollutants generated in kitchens and heating areas can also spread into living areas where children and other household members are exposed [11, 12]. Globally, despite the health risks of the use of biomass fuels such as animal dung, crop residues, wood, and coal for cooking and heating purposes continues, approximately 3 billion people continue to use these various biomass fuels worldwide [13, 14]. The recent analysis of demographic and health data in Afghanistan illustrated that in addition to using such fuels, the location used to cook the food had a significant association with acute respiratory infections [15]. The evidence indicates controlling the exposure to biomass fuels could reduce the risk of adverse children and adult health outcomes by $20-50 \%$ [16]. Outdoor cooking and stove ventilation were some of the measures that substantially reduced the risks $[15,17,18]$.

In Ethiopia, there are 55 deaths per 1000 live births in children under-five due to acute respiratory infection, placing it among the world's highest mortality rates [19]. Prior studies indicated that maternal age, residence, maternal hand hygiene information [20], maternal literacy, smoking, use of animal dung as a fuel source, nutritional status [21], absence of a separate kitchen, and lack of windows were significantly associated with acute respiratory infections [22-25].

In Ethiopia, more than $90 \%$ of the population uses solid biomass fuel [26-28]; there is a paucity of evidence on the location of cooking food and the association with ARI in children under-five, based on a nationally representative community-based study. Moreover, there is limited evidence on whether there is variability in the infection over time. Therefore, the current study is intended to assess the association of the location of cooking food with acute respiratory infection in under-five children and its variability in households and surveys based on demographic and health survey data collected in three different time periods. The results will provide evidence for policymakers for better intervention in progressing the under-five mortality and morbidity of the SDG strategic plan.

\section{Methods}

\section{Study setting}

According to the world population review report in 2020, Ethiopia has an estimated 114.96 million population, making it the second-largest country in Africa, the twelfth most populous country worldwide [29]. Ethiopia has a population growth rate of $3.02 \%$ per year and a fertility rate of $4.73 \%$ [29, 30]. The administrative structure consists of nine regional states (Tigray, Afar, Amhara, Oromiya, Somali, Benishangul-Gumuz, Southern Nations Nationalities and People (SNNP), Gambela, and Harari) and two city administrations (Addis Ababa and Dire Dawa) [31].

\section{Study design, sample size, and sampling procedure}

The Ethiopian Demographic and Health survey 2005, 2011, and 2016 were used for the current study. The surveys were conducted among women aged 15-49 years from urban and rural areas in the nine regions and two cities. During the surveys, each of the regions was stratified into urban and rural areas. Samples of Enumeration Areas (EAs) were selected independently from each stratum from where the samples were determined using a stratified, two-stage cluster design. The number of EAs from the 2016 survey was 645 (202 from urban and 443 from rural); for the 2011 survey, 624 (187 from urban and 437 from rural areas); for the 2005 survey, and 540 (145 from urban and 395 from rural areas) [26-28]. The number of households and clusters included was 14,500 from 540 clusters in 2005; 17,817 from 624 clusters in 2011; and 16,650 from 645 clusters in 2016. The sampling procedure applied is as follows: first, clusters were selected from the enumeration area list from the population and housing census sample frame. The sampling frame for the 2005 survey was based on the 1997 census; the 2011 and 2016 surveys were based on the 2007 census. Secondly, the households were selected after listing the households in all selected enumeration areas for the sampling frame [26-28]. Based on the data obtained, the number of children included in the three surveys was 30 , 985 (9517 from the 2005 survey, 11,176 from the 2011 survey, and 10,291 from the 2016 survey). 


\section{Method of data collection}

The data collection method was face-to-face interviewing of mothers or respondents, as indicated elsewhere [26-28].

\section{Outcome variable}

The outcome of interest was acute respiratory infection (ARI). The DHS survey assessed whether the children of participating mothers suffered from a cough in the last 2 weeks before the survey. The respondents were further probed whether the cough was associated with shortness of breath or rapid breathing problems during the specified period. Therefore, children who suffered a cough with shortness of breathing were considered to have ARI.

During each survey, households were asked about the type of fuels they reportedly used and the place of cooking food. Respondents were categorized into solid biomass fuel users (families that used wood, charcoal, kerosene, grass, crop products) or non-solid biomass fuel users (electricity, liquid petroleum gas, natural gas, biogas). Besides, households were asked about the location where they cooked the food (either inside the house, outside, or in a separate building).

\section{Independent variables}

Variables were selected based on prior findings that revealed their association with children's ARI $[5,15,23,25$, 32-36]. These were the child's age, place of cooking food, maternal age, maternal education, paternal education, residency, nutrition status, household wealth quintile, frequency of watching television, frequency of listening to radio, maternal occupation, and paternal occupation, as indicated elsewhere. Stunting, underweight, and wasting was assessed based on the World Health Organization Child Growth Standards and the National Center for Health Statistics (NCHS)/WHO international growth reference [37].

Variables were classified into three levels: (1) childlevel variables (age of the child, sex of the child, size of the child, child weight, child stunting, child wastage, and breastfeeding), (2) household-level variables (wealth quintiles, water sources, toilet type, residence, maternal education, maternal occupation, paternal education, paternal occupation, frequency of listening radio, and frequency of watching television), and (3) survey-level variables (the type of fuel, location of cooking food). However, the type of fuel was excluded from analysis as more than $98 \%$ of households were reportedly using solid biomass fuel.

\section{Data analysis}

Data were analyzed using the Stata 14 version (Stata Corp LP, College Station, TX, USA). The "svy" command was used to weigh the survey data to adjust cluster sampling design in the merged data set of three surveys. First, the study population's characteristics were presented by ARI status and by exposure variables. The association of ARI with the place of cooking food was examined using a three-level multilevel logistic regression to assess variability in the outcome using a household and survey as level. A multilevel analysis was used due to the level of observation at which the child's ARI status is nested within households and surveys. Inclusion of the higher-level (household and survey-level) characteristics as child-level factors can lead to the understatement of standard error, as one value was replicated across all members of the same group. Using a multilevel model, the value was applied once, at the group level, and information from the pooled regression helped generate reliable estimates even for groups with insufficient numbers of first-level observations. The model also allowed to include error terms at each level, tracking changes in variance across models [38, 39]. The model is based on the following equation:

$$
\begin{aligned}
& \mathrm{Y}_{\mathrm{i}}=\mathrm{a}_{\mathrm{jk}}+\beta \mathrm{X}_{\mathrm{i}}+\mathrm{e}_{\mathrm{i}} \quad i=1,-\cdot-\cdot-\cdot-\cdot----, \mathrm{I} \\
& a_{j k}=g_{0}^{j}+g_{k}+e_{j} j=1,-----------, j \quad k \\
& =1--\cdot-\cdot-\cdot--, \mathrm{K} \\
& \mathrm{g}_{\mathrm{k}}=\mathrm{l}_{0}+\mathrm{l}_{\mathrm{k}}+\mathrm{D}_{\mathrm{k}}+\mathrm{e}_{\mathrm{i}} \mathrm{k}=1,-\cdot-\cdot-\cdot-\cdot-\cdot--\cdot, \mathrm{K}
\end{aligned}
$$

where $Y_{\mathrm{i}}$ the binary response of mother on child $\mathrm{i}$ about ARI status in the $j$ household in $k$ survey, $\boldsymbol{a}_{\mathrm{jk}}$ and $\beta$ are the intercept and coefficient vector for child-level variables $X_{\mathrm{i}}, g_{0}^{\mathrm{j}}$ is a household-specific intercept, and $g_{\mathrm{k}}$ survey-level intercept which is a function of survey-level variable $D_{\mathrm{k}}$, survey-level coefficient $l_{\mathrm{k}}$, and survey-level intercept $l_{0}$. Finally, $e_{\mathrm{i}}, e_{\mathrm{j}}$, and $e_{\mathrm{k}}$ are error terms at each level.

\section{Model building}

Before the model building, a binary multilevel logistic regression was applied. Those variables with a $p$ value of less than 0.2 were considered for the multivariable analysis to estimate the adjusted odds ratios and the extent of random variations between households and surveys. Three models containing variables of interest was fitted using the "svy: xtmelogit" command in Stata: model-I (empty model): model fitted without factors to test the random variability in the intercept, model-II: to assess the effect of the survey-level variable and (random intercept and slope for survey-level variables), and model-III (full model): to evaluate the impact of survey-level variables and other variables and simultaneously. In a full model, the child-related variables included were age, sex, birth weight, and nutrition status and the householdrelated variables were wealth quintiles, listening radio, watching television, drinking water source, toilet type, 
maternal age, maternal education, paternal education, paternal occupation, maternal occupation, and residence. All statistical tests were considered significant at $p$ value $<0.05$.

\section{Ethical consideration}

The three EDHS were conducted after obtaining ethical approval from the ICF Institutional Review Board (IRB), Ethiopia Health and Nutrition Research Institute Review Board, and the Ministry of Science and Technology. The data collectors were instructed in how to obtain informed consent statement and voluntary participation prior to data collection. The confidentiality of the information was maintained. For this particular study, a brief description of the protocol was submitted to the MEASURE DHS program to access and analyze the data.

\section{Result}

\section{Socio-demographic characteristics of households with} under-five children

Nine thousand nine hundred seventy-one children were included in the analysis from the 2005 survey, 10729 from the 2011 survey, and 10195 from the 2016 survey, with a total of 30895. Two-fifths of the children had an average size, and nearly one-fifth of the children had an age of 3 years and 4 years each. In total, nearly ninetenths of the children reside in rural, $42 \%$ of the children were stunted, $30 \%$ were underweight, and $17 \%$ were wasted. The majority of participants were from rural areas, and about two-fifths were stunted. Stunting decreased over time, with $50 \%$ stunting in $2005,42 \%$ in 2011 , and $38 \%$ in 2016. Similarly, the number of underweight children also decreased from 50\% (2005), 27\% (2011), and 24\% in 2016. Households' experience of listening to the radio twice a week in 2005 was nearly $25 \%$ which increased to $32 \%$ in 2011 and dropped to $13 \%$ in 2016. On the other hand, household television watching increased to three times a week in $0.7 \%$ in 2005 to $8.3 \%$ in 2011 and $8.1 \%$ in 2016. Of mothers included in the survey, the majority was unemployed and more than 70\% did not attend school (Table 1).

\section{Type of fuels used in the house and place of cooking food}

The pooled data revealed that the proportion of households that used a solid biomass fuel as an energy source was $98.4 \%(95 \% \mathrm{CI}=98.1,98.6)$ with $98.8 \%(95 \% \mathrm{CI}=$ 98.4, 99.0), 99.5\% (95\% CI $=99.2,99.7)$, and $96.9 \%$ (95\% $\mathrm{CI}=96.2,97.4)$, respectively, in 2005, 2011, and 2016. The data concerning cooking foods' locations indicate that $57 \%, 35 \%$, and $8 \%$ cooked the foods inside the house, a separate building, and outside the house, respectively. The cooking location in each survey year shows that $71 \%$ of households cooked inside the house in 2005, and the number dropped to $43 \%$ in 2016 (Fig. 1). There was a declining trend in cooking food inside the house and an increasing trend of cooking in a separate house. Cooking the food outside the house increased from $5.8 \%$ in 2005 to $10.7 \%$ in 2016.

\section{Acute respiratory infection}

Of the 30,895 children included in three surveys, $11.9 \%$ had an acute respiratory infection, $12.7 \%$ in $2005,11.9 \%$ in 2011 , and $11.1 \%$ in the 2016 survey. The results indicate a decline in the number of children with ARI from 2005 to 2011, although only slightly decreased from 2011 to 2016.

\section{The distribution of ARI across variable categories}

The prevalence of acute respiratory infection is $12.6 \%$ in the households that cooked the food inside the house. The prevalence of the disease is higher in the households that cooked the food outside the house and in a separate building with the respective percentage of $9.6 \%$ and $11.2 \%$. The prevalence of ARI among families using solid biomass fuel is $11 \%$ compared with those who used nonsolid fuel, which is about $6 \%$. In addition, a low prevalence of infection was found in those mothers who reported ever breastfeeding, high paternal education status, and professional workers. Similarly, children of mothers with a high education status, between 44 and 49 years old reported a low ARI. Again, the mothers listening to the radio daily, watching television daily, and in the highest wealth quintiles also reported a lower ARI (Table 2).

\section{The association of ARI with place of cooking food in the house}

The empty model indicates a variation in the risk of having ARI among children in households and surveys with respect to random intercepts of 0.13 and 0.37 . In modelII, where the survey-level variables (place of food cooking) were used, families cooking the food outdoor had a $30 \%$ (95\% CI $=0.56,0.88)$ lower risk of having underfive children with ARI compared to those cooking inside the home. The random intercepts for the households and survey in model-II also indicate significant differences among households within the survey (between households of the same study) and surveys having under-five children with ARI. The full model (after including all the variables in the models) showed that cooking the food outdoor had a $44 \%$ (AOR $=0.56,95 \%$ $\mathrm{CI}=0.40,0.75)$ lower risk of having under-five children with ARI compared to cooking inside the house. Similarly, the children's risk of having ARI among households that cooked the food in a separate kitchen was $19 \%$ less likely $(\mathrm{AOR}=0.81,95 \% \mathrm{CI}=0.69,0.96)$. The standard deviations of random intercepts and random slopes in a full model were higher than their respective 
Table 1 Socio-demographics of households and under-five children characteristics, EDHS 2005-2016

\begin{tabular}{|c|c|c|c|c|}
\hline \multirow[t]{2}{*}{ Characteristics } & \multicolumn{3}{|c|}{ Survey year, $N(\%)$} & \multirow{2}{*}{$\begin{array}{l}\text { Total } \\
N(\%)\end{array}$} \\
\hline & 2005 & 2011 & 2016 & \\
\hline \multicolumn{5}{|l|}{ Residence } \\
\hline Urban & $762(7.0)$ & $1427(12.5)$ & $1149(10.7)$ & $3338(10.1)$ \\
\hline Rural & $10,075(93.0)$ & $9982(87.5)$ & 9559 (89.3) & 29616 (89.9) \\
\hline \multicolumn{5}{|l|}{ Stunting } \\
\hline Normal & $2222(50.2)$ & $6210(58.6)$ & 5987 (61.9) & $14420(58.4)$ \\
\hline Stunted & $2208(49.8)$ & $4397(41.5)$ & 3679 (38.1) & $10283(41.6)$ \\
\hline \multicolumn{5}{|l|}{ Weight } \\
\hline Normal & $2222(50.2)$ & $7747(73.0)$ & $7368(76.0)$ & $17337(70.1)$ \\
\hline Underweight & $2208(49.8)$ & $2860(27.0)$ & $2327(24.0)$ & 7395 (29.9) \\
\hline \multicolumn{5}{|l|}{ Wasting } \\
\hline Normal & $2222(50.2)$ & 9637 (90.9) & $8710(89.9)$ & $20569(83.2)$ \\
\hline Wasted & 2208 (49.8) & $971(9.2)$ & $978(10.1)$ & $4156(16.8)$ \\
\hline \multicolumn{5}{|l|}{ Breast feeding } \\
\hline Never & $380(3.5)$ & $332(2.9)$ & $520(4.9)$ & $1231(3.8)$ \\
\hline Ever & $10,302(96.5)$ & $11,028(97.1)$ & $10,189(95.2)$ & 31519 (96.2) \\
\hline \multicolumn{5}{|l|}{ Child age in years } \\
\hline 0 years & $2211(22.0)$ & $2324(21.5)$ & $2243(21.9)$ & $6778(21.8)$ \\
\hline 1 years & 1869 (18.6) & $1878(17.4)$ & $1966(19.2)$ & $5713(18.4)$ \\
\hline 2 years & $1875(18.7)$ & $2016(18.7)$ & $1911(18.7)$ & $5803(18.7)$ \\
\hline 3 years & $2081(20.7)$ & $2342(21.7)$ & $1973(19.3)$ & $6396(20.6)$ \\
\hline 4 years & $2000(19.9)$ & $2229(20.7)$ & $2150(21.0)$ & $6379(20.5)$ \\
\hline \multicolumn{5}{|l|}{ Size of child } \\
\hline Very small & $2411(22.3)$ & $2191(19.3)$ & $1890(17.8)$ & $6492(19.8)$ \\
\hline Smaller than average & $1013(9.4)$ & $1451(12.8)$ & $1491(14.0)$ & 3954 (12.1) \\
\hline Average & $4343(40.2)$ & $4365(38.4)$ & $4457(42.0)$ & $13165(40.2)$ \\
\hline Larger than average & $792(7.3)$ & $1005(8.8)$ & $1072(10.1)$ & $2868(8.8)$ \\
\hline Very large & $2237(20.7)$ & $2357(20.7)$ & $1712(16.1)$ & $6307(19.2)$ \\
\hline \multicolumn{5}{|l|}{ Education of father } \\
\hline No education & $6322(58.9)$ & $5651(50.2)$ & $4866(48.2)$ & $16839(52.5)$ \\
\hline Primary & $3256(30.4)$ & $4722(42.0)$ & 4028 (39.9) & $12006(37.4)$ \\
\hline Secondary & $1041(9.7)$ & $530(4.7)$ & $771(7.6)$ & $2342(7.3)$ \\
\hline Higher & $109(1.0)$ & $351(3.1)$ & $438(4.3)$ & $898(2.8)$ \\
\hline \multicolumn{5}{|l|}{ Occupation of father } \\
\hline Did Not Work & $46(0.43)$ & $93(0.8)$ & $781(7.7)$ & $920(2.9)$ \\
\hline Professional & $170(1.6)$ & $325(2.9)$ & $402(4.0)$ & $896(2.8)$ \\
\hline Sales & $547(5.1)$ & $867(7.7)$ & $677(6.7)$ & $2091(6.6)$ \\
\hline Agriculture & $9468(88.3)$ & $9057(80.3)$ & $6719(66.4)$ & $25244(79.4)$ \\
\hline Service & $60(0.6)$ & $162(1.4)$ & $267(2.6)$ & $489(1.7)$ \\
\hline Skilled & $245(2.3)$ & $591(5.2)$ & $549(5.4)$ & $1385(4.4)$ \\
\hline Unskilled & $178(1.7)$ & $116(1.0)$ & $364(3.6)$ & $658(2.1)$ \\
\hline Other & $15(0.1)$ & $69(0.6)$ & 359 (3.6) & $443(1.4)$ \\
\hline
\end{tabular}


Table 1 Socio-demographics of households and under-five children characteristics, EDHS 2005-2016 (Continued)

\begin{tabular}{|c|c|c|c|c|}
\hline \multirow[t]{2}{*}{ Characteristics } & \multicolumn{3}{|c|}{ Survey year, $N(\%)$} & \multirow{2}{*}{$\begin{array}{l}\text { Total } \\
N(\%)\end{array}$} \\
\hline & 2005 & 2011 & 2016 & \\
\hline \multicolumn{5}{|l|}{ Occupation of mother } \\
\hline Did not work & 7671 (70.9) & $5306(46.9)$ & $5975(55.8)$ & $18953(57.5)$ \\
\hline Sales & $764(7.1)$ & $1860(16.5)$ & $1234(11.5)$ & $3858(11.7)$ \\
\hline Agriculture & $2042(18.9)$ & $3106(27.5)$ & $2398(22.4)$ & $7546(22.9)$ \\
\hline Skilled & $154(1.4)$ & $790(7.0)$ & $395(3.7)$ & $1339(4.1)$ \\
\hline Other & $187(1.7)$ & $147(2.2)$ & $706(6.6)$ & $1139(3.5)$ \\
\hline \multicolumn{5}{|l|}{ Education of mother } \\
\hline No education & $8595(79.3)$ & $7961(69.8)$ & $7105(66.4)$ & $23661(71.8)$ \\
\hline Primary & $1801(16.6)$ & $3058(26.8)$ & $2864(26.8)$ & $7724(23.4)$ \\
\hline Secondary & $400(3.7)$ & $237(2.1)$ & $490(4.6)$ & $1127(3.4)$ \\
\hline Higher & $42(0.4)$ & $153(1.3)$ & $248(2.3)$ & $442(1.3)$ \\
\hline \multicolumn{5}{|l|}{ Age of mothers } \\
\hline $15-19$ & $537(5.0)$ & $447(3.9)$ & $353(3.3)$ & $1337(4.1)$ \\
\hline $20-24$ & $2146(19.8)$ & $2247(19.7)$ & $2001(18.7)$ & $6395(19.4)$ \\
\hline $25-29$ & 3109 (28.7) & $3685(32.3)$ & $3262(30.5)$ & $10,056(30.5)$ \\
\hline $30-34$ & $2270(21.0)$ & $2285(20.0)$ & $2443(22.8)$ & $6998(21.2)$ \\
\hline $35-39$ & $1666(15.4)$ & $1741(15.3)$ & $1713(16.0)$ & $5120(15.5)$ \\
\hline $40-44$ & $768(7.1)$ & $743(6.5)$ & $705(6.6)$ & $2217(6.7)$ \\
\hline $45-49$ & $341(3.1)$ & $260(2.3)$ & $230(2.2)$ & $830(2.5)$ \\
\hline \multicolumn{5}{|c|}{ Listening radio in the last week } \\
\hline Not at all & $7049(65.1)$ & $5728(50.2)$ & $7894(73.7)$ & $20671(62.7)$ \\
\hline Twice a week & $2601(24.0)$ & $3658(32.1)$ & $1386(12.9)$ & $7645(23.2)$ \\
\hline Three times a week & $326(3.0)$ & $2015(17.7)$ & $1428(13.3)$ & $3769(11.4)$ \\
\hline Almost everyday & $860(7.9)$ & & & $860(2.6)$ \\
\hline \multicolumn{5}{|c|}{ Watching television in the last week } \\
\hline Not at all & $9931(93.2)$ & 7699 (67.6) & $8814(82.3)$ & $26443(80.3)$ \\
\hline Twice a week & $652(6.1)$ & $2,750(24.1)$ & 1,031 (9.6) & $4433(13.5)$ \\
\hline Three times a week & $69(0.7)$ & $944(8.3)$ & $863(8.1)$ & $1876(5.7)$ \\
\hline \multicolumn{5}{|l|}{ Toilet type } \\
\hline Improved & $574(5.3)$ & $1393(12.4)$ & $1044(9.8)$ & $3011(9.2)$ \\
\hline Unimproved & $10,224(94.7)$ & 9878 (87.6) & $9597(90.2)$ & $29699(90.8)$ \\
\hline \multicolumn{5}{|l|}{ Water source } \\
\hline Improved & $6156(57.0)$ & $5188(46.1)$ & $5994(64.3)$ & $17338(55.3)$ \\
\hline Unimproved & $4639(43.0)$ & $6074(53.9)$ & $3325(35.7)$ & $14038(44.7)$ \\
\hline
\end{tabular}

standard errors showing variability from survey to survey. However, the standard deviation of the household's random intercepts was near zero, meaning there was no house to house variation in this term (Table 3).

\section{Discussion}

The three surveys show that more than $98 \%$ of the households use solid biomass fuel for cooking food even if these fuels are known to be emitting a large number of indoor air pollutants which implies that the children's exposure to biomass and charcoal fuel leads to a high chance of developing ARI [40]. This study found only 9.6\% of the total households prepared food outside the living quarters, which was different from other studies conducted in African countries that reported 18\% in East Africa and 43\% in West Africa [41].

The current finding shows a lower risk of having an ARI in children under-five in households that cook the 


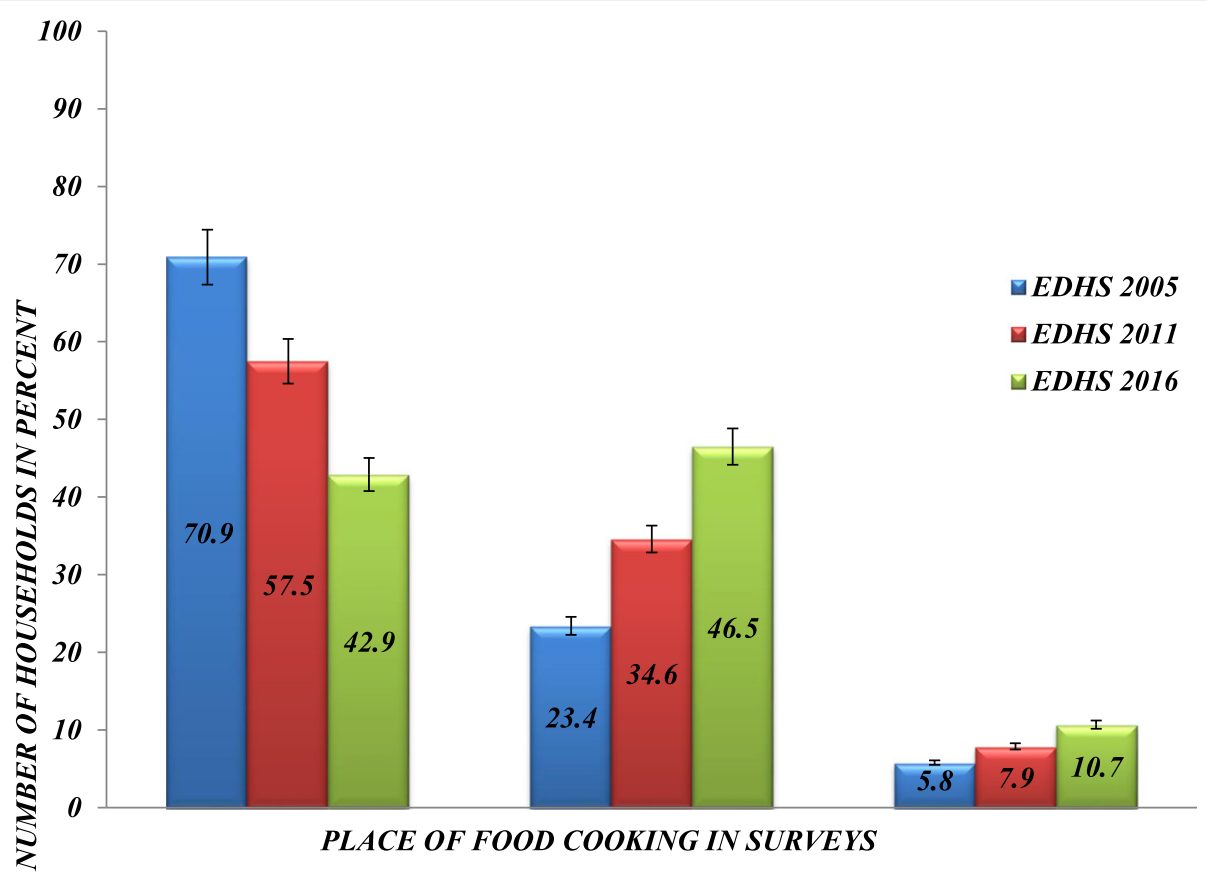

Fig. 1 Household food cooking place, Ethiopian Demographic and Health Surveys, 2005-2016. The percent distribution is calculated by dividing the number of households reportedly cooking food inside the house, outside the house and in separate house to total number of households in each survey

food outside the home compared to those cooking inside the house (after controlling for other variables). This finding is consistent with a prior study conducted in 27 African countries [41] and Afghanistan [15]. This indicates that cooking food in a separate building will lower the risk of ARI in children compared to cooking inside a building; this complies with findings from Tanzania [42], Nigeria [43], and the most recent one from India [18], all based on demographic and health survey data.

The older children have a lower ARI risk than children below 1 year, suggesting less exposure to induced indoor air pollutants due to less time spent indoors. Mothers with younger children prefer to cook indoors while caring for their children. The finding is similar to previous studies in urban areas of the Oromia region, Ethiopia [33]; in Wondo-Genet district, southern Ethiopia [23]; and in Afghanistan [34].

The mother's watching of television at least once a week was protective of her child to develop ARI, which is consistent with the prior study [32]. Watching television may increase awareness about the risks of solid biomass fuel, cooking place, and disseminate knowledge about the programs and policies related to their child's healthcare services.

The variation in the number of children with ARI among households of different surveys from multilevel modeling suggests a change in the practice of families using non-solid biomass or preparing their food outside and/or ventilated kitchen. This could result from a country-level effort to improve the use of non-solid biomass fuels, and improved stove use, by health extension workers since 2003 [44-48].

The higher risk of having children under-five with ARI in the households while cooking inside compared to both the outdoor environment and separate buildings implies that exposures to a high concentration of particulate matter (PM10) and $\mathrm{NO}_{2}$ are predisposing factors for ARI, as reported in a prior study in Tanzania [42], and poor ventilation of the house [40]. Thus, children in households that cook food inside the homes were exposed to the pollutants, resulting in lung function impairment. A prior finding revealed a significant reduction in forced expiratory lung volumes in biomass fuel users [42]. The histopathological finding in under-five children who spent, on average, $4-5 \mathrm{~h}$ a day inside the kitchen revealed a detailed necroscopy [43]. Biomass smoke exposure increased forced expiratory volume (FEV) 1 /force vital capacity (FVC), indicating a significant loss of vital capacity sufficiently high to be responsible for both obstructive and restrictive pulmonary diseases in long exposure [44]. As the duration and the intensity of exposure increase, the probability of having altered pulmonary function test results is higher [26]. 
Table 2 Acute respiratory infection on under-five children across different variable selected, EDHS 2005-2016

\begin{tabular}{|c|c|c|c|c|c|c|c|c|c|}
\hline \multirow[t]{2}{*}{ Variables } & \multirow[t]{2}{*}{ Category } & \multicolumn{4}{|c|}{ Weighted frequency } & \multicolumn{3}{|c|}{ ARI, weighted percentage $(95 \% \mathrm{Cl})$} & \multirow[b]{2}{*}{ Pooled } \\
\hline & & 2005 & 2011 & 2016 & Pooled & 2005 & 2011 & 2016 & \\
\hline \multirow[t]{2}{*}{ Breast feeding of child } & Never & 178 & 153 & 372 & 703 & $13.1(6.1,26.0)$ & $8.7(3.8,18.5)$ & $10.1(5.0,19.3)$ & $10.5(6.7,16.2)$ \\
\hline & Ever & 9696 & 10545 & 9823 & 30064 & $12.7(11.5,14.0)$ & $11.9(10.8,13.1)$ & $11.2(10.0,12.5)$ & $11.9(11.3,12.7)$ \\
\hline \multirow[t]{4}{*}{ Father's education } & No education & 5750 & 5257 & 4636 & 15643 & $12.0(10.6,13.5)$ & $12.3(10.7,14.0)$ & $10.6(9.0,12.5)$ & $11.7(10.8,12.6)$ \\
\hline & Primary & 3021 & 4474 & 3827 & 11322 & $14.0(12.1,16.1)$ & $11.8(10.2,13.5)$ & $12.9(10.9,15.2)$ & $12.7(11.6,13.9)$ \\
\hline & Secondary & 992 & 514 & 748 & 2254 & $13.8(11.0,17.3)$ & $10.3(6.9,15.0)$ & $9.7(6.4,14.5)$ & $11.6(9.7,13.9)$ \\
\hline & Higher & 107 & 332 & 411 & 851 & $3.3(1.0,10.5)$ & $9.5(5.2,16.5)$ & $3.7(1.8,7.3)$ & $5.9(3.8,9.0)$ \\
\hline \multirow[t]{8}{*}{ Father's occupation } & Did not work & 43 & 89 & 736 & 869 & $22.5(9.6,44.4)$ & $19.7(8.0,40.7)$ & $11.6(7.9,16.8)$ & $13.0(9.2,17.8)$ \\
\hline & Professional & 166 & 311 & 391 & 868 & $6.2(2.9,12.5)$ & $11.0(6.2,18.9)$ & $4.4(2.4,7.9)$ & $7.1(4.8,10.4)$ \\
\hline & Sales & 516 & 830 & 653 & 1999 & $7.6(5.1,11.2)$ & $11.7(8.5,15.8)$ & $11.0(7.5,0.160)$ & $10.4(8.4,12.8)$ \\
\hline & Agriculture & 8674 & 8474 & 6384 & 23533 & $13.2(11.9,14.6)$ & $12.1(10.9,13.4)$ & $11.99(10.3,13.7)$ & $12.5(11.7,13.3)$ \\
\hline & Services & 58 & 149 & 253 & 461 & $12.1(5.0,26.8)$ & $14.8(7.1,0.283)$ & $10.6(6.2,17.5)$ & $12.1(8.1,17.8)$ \\
\hline & Skilled & 232 & 569 & 537 & 1338 & $12.7(7.2,21.4)$ & $7.9(5.0,12.1)$ & $11.5(7.9,16.6)$ & $10.2(7.8,13.1)$ \\
\hline & Unskilled & 164 & 111 & 337 & 613 & $11.0(6.6,17.8)$ & $12.5(5.0,27.9)$ & $12.1(8.2,0.176)$ & $11.9(8.8,15.9)$ \\
\hline & Other & 15 & 68 & 341 & 425 & & $18.3(8.8,0.344)$ & $5.8(3.4,9.6)$ & $7.6(4.8,11.9)$ \\
\hline \multirow[t]{5}{*}{ Mother's occupation } & Did not work & 7044 & 5009 & 5679 & 17732 & $11.8(10.3,13.4)$ & $11.3(9.9,13.0)$ & $10.3(8.9,11.9)$ & $11.2(10.2,12.0)$ \\
\hline & Sales & 709 & 1762 & 1172 & 3643 & $16.1(12.5,20.4)$ & $13.0(10.7,15.8)$ & $12.8(10.2,16.0)$ & $13.6(11.9,15.4)$ \\
\hline & Agriculture & 1880 & 2889 & 2305 & 7074 & $15.5(12.9,18.4)$ & $12.6(10.9,14.6)$ & $12.8(10.4,15.9)$ & $13.5(12,2,14.2)$ \\
\hline & Skilled & 147 & 735 & 372 & 1254 & $9.6(4.7,18.7)$ & $10.8(7.7,15.0)$ & $11.7(6.8,19.6)$ & $10.9(8.3,14.2)$ \\
\hline & Other & 174 & 240 & 668 & 1082 & $9.9(5.6,16.9)$ & $(8.9(5.1,0.149)$ & $8.7(5.9,12.6)$ & $8.9(6.8,11.7)$ \\
\hline \multirow[t]{4}{*}{ Mother's education } & No education & 7863 & 7446 & 6750 & 22059 & $12.6(11.3,14.1)$ & $11.8(10.5,13.2)$ & $11.1(9.6,12.7)$ & $11.9(11.1,12.7)$ \\
\hline & Primary & 1679 & 2905 & 2734 & 7318 & $13.8(11.3,16.6)$ & $12.4(10.5,14.5)$ & $12.4(10.4,14.6)$ & $12.7(11.5,14.0)$ \\
\hline & Secondary & 388 & 230 & 472 & 1090 & $10.4(6.7,15.9)$ & $10.6(6.1,17.9)$ & $8.2(5.3,12.5)$ & $9.5(7.3,12.4)$ \\
\hline & Higher & 42 & 147 & 239 & 428 & $2.2(0.6,7.7)$ & $8.4(4.2,16.2)$ & $4.8(2.3,10.0)$ & $5.8(3.5,9.5)$ \\
\hline \multirow{5}{*}{$\begin{array}{l}\text { Household wealth } \\
\text { quintile }\end{array}$} & Poorest & 1904 & 1613 & 1510 & 5027 & $12.2(10.0,14.8)$ & $11.7(9.4,14.4)$ & $10.7(8.3,13.6)$ & $11.6(10.2,13.1)$ \\
\hline & Poorer & 2206 & 3101 & 2551 & 7858 & $10.4(8.6,12.5)$ & $12.0(10.2,14.0)$ & $12.0(9.7,14.7)$ & $11.5(10.4,12.8)$ \\
\hline & Middle & 2331 & 2553 & 2738 & 7622 & $14.6(12.2,17.4)$ & $12.0(9.9,14.5)$ & $11.8(9.7,14.4)$ & $12.7(11.4,14.2)$ \\
\hline & Higher & 2422 & 2135 & 2296 & 6853 & $9.7(12.7,17.0)$ & $11.4(9.5,13.7)$ & $11.9(9.7,14.5)$ & $12.7(11.5,14.1)$ \\
\hline & Highest & 1109 & 1327 & 1100 & 3536 & $11.7(7.5,12.5)$ & $12.3(9.5,15.8)$ & $6.5(4.4,9.4)$ & $9.7(8.2,11.4)$ \\
\hline \multirow[t]{2}{*}{ Child sex } & Male & 5050 & 5531 & 5222 & 15803 & $12.8(11.2,14.5)$ & $11.7(10.3,13.3)$ & $11.0(9.6,12.5)$ & $11.8(11.0,12.7)$ \\
\hline & Female & 4921 & 5198 & 4973 & 15092 & $12.6(11.1,14.3)$ & $12.1(10.8,13.5)$ & $11.3(0.097,13.1)$ & $12.0(11.1,12.9)$ \\
\hline \multirow[t]{5}{*}{ Child age } & $O$ years & 2208 & 2322 & 2243 & 6773 & $15.8(13.3,18.7)$ & $14.7(12.7,17.0)$ & $13.4(11.2,16.0)$ & $14.6(13.3,16.1)$ \\
\hline & 1 years & 1865 & 1875 & 1965 & 5705 & $14.7(12.6,17.1)$ & $13.3(11.1,15.8)$ & $13.8(11.5,16.5)$ & $13.9(12.6,15.3)$ \\
\hline & 2 years & 1865 & 2007 & 1892 & 5763 & $13.2(11.1,15.6)$ & $12.0(9.9,14.4)$ & $11.0(8.8,13.7)$ & $12.1(10.8,13.5)$ \\
\hline & 3 years & 2063 & 2321 & 1960 & 6344 & $10.9(9.2,12.9)$ & $11.0(9.1,13.1)$ & $10.3(8.4,12.5)$ & $10.7(9.6,11.9)$ \\
\hline & 4 years & 1970 & 2204 & 2135 & 6310 & $8.7(7.1,10.6)$ & $8.6(6.9,10.6)$ & $7.1(5.5,9.3)$ & $8.1(7.1,9.3)$ \\
\hline \multirow[t]{7}{*}{ Age of mother } & $15-19$ & 485 & 416 & 348 & 1249 & $13.0(9.0,18.4)$ & $15.1(9.9,22.4)$ & $13.6(8.3,21.3)$ & $13.9(10.9,17.4)$ \\
\hline & $20-24$ & 1959 & 2109 & 1887 & 5955 & $13.2(10.7,16.2)$ & $11.7(9.7,14.1)$ & $13.1(11.0,15.6)$ & $12.6(11.3,14.1)$ \\
\hline & $25-29$ & 2874 & 3442 & 3089 & 9405 & $13.1(11.1,15.4)$ & $11.9(10.2,13.7)$ & $9.8(8.1,11.8)$ & $11.6(10.5,12.7)$ \\
\hline & $30-34$ & 2081 & 2171 & 2350 & 6603 & $12.1(10.1,14.4)$ & $11.0(9.1,13.2)$ & $12.2(9.9,15.0)$ & $11.7(10.5,13.1)$ \\
\hline & $35-39$ & 1558 & 1637 & 1623 & 4818 & $12.5(10.0,15.5)$ & $11.9(9.8,14.5)$ & $9.8(7.7,12.4)$ & $11.4(10.1,12.9)$ \\
\hline & $40-44$ & 709 & 714 & 675 & 2098 & $12.8(9.4,17.2)$ & $14.6(10.0,20.8)$ & $19.8(6.9,13.8)$ & $12.4(10.1,15.2)$ \\
\hline & $44-49$ & 306 & 240 & 223 & 768 & $10.7(6.6,16.8)$ & $8.0(4.7,13.3)$ & $11.8(6.6,20.2)$ & $10.2(7.5,13.7)$ \\
\hline \multirow[t]{2}{*}{ Type of fuel used } & Solid biomass fuel & 9811 & 10553 & 9809 & 12995 & $12.8(11.6,14.1)$ & $11.9(10.8,13.1)$ & $11.2(10.0,12.5)$ & $11.0(11.3,12.7)$ \\
\hline & Non-solid fuel & 130 & 53 & 326 & 508 & $4.7(2.7,8.0)$ & $6.5(1.3,26.8)$ & $6.8(3.8,12.0)$ & $6.2(3.9,9.8)$ \\
\hline \multirow{3}{*}{$\begin{array}{l}\text { Location of food } \\
\text { preparation or cooking }\end{array}$} & Inside house & 7050 & 6109 & 4328 & 17488 & $13.4(11.9,15.1)$ & $12.2(10.7,13.9)$ & $12.0(10.4,13.9)$ & $12.6(11.2,13.6)$ \\
\hline & Separate building & 2343 & 3770 & 4770 & 10883 & $12.0(10.1,14.1)$ & $11.0(9.4,12.7)$ & $11.0(9.4,12.9)$ & $11.2(10.2,12.3)$ \\
\hline & Outside the house & 575 & 843 & 1088 & 2506 & $6.8(4.5,10.2)$ & $12.0(10.0,16.8)$ & $8.3(6.0,11.4)$ & $9.6(7.9,11.5)$ \\
\hline
\end{tabular}


Table 2 Acute respiratory infection on under-five children across different variable selected, EDHS 2005-2016 (Continued)

\begin{tabular}{|c|c|c|c|c|c|c|c|c|c|}
\hline \multirow[t]{2}{*}{ Variables } & \multirow[t]{2}{*}{ Category } & \multicolumn{4}{|c|}{ Weighted frequency } & \multicolumn{3}{|c|}{ ARI, weighted percentage $(95 \% \mathrm{Cl})$} & \multirow[b]{2}{*}{ Pooled } \\
\hline & & 2005 & 2011 & 2016 & Pooled & 2005 & 2011 & 2016 & \\
\hline \multirow[t]{5}{*}{ Child size } & Very large & 2175 & 2028 & 1790 & 5992 & $14.9(12.2,18.1)$ & $11.0(9.1,13.3)$ & $14.1(11.7,16.9)$ & $13.3(11.9,15.0)$ \\
\hline & Larger than average & 943 & 1317 & 1417 & 3677 & $10.1(7.8,12.8)$ & $12.2(9.9,14.8)$ & $7.7(5.8,10.2)$ & $9.9(8.6,11.4)$ \\
\hline & Average & 4043 & 4184 & 4275 & 12503 & $11.7(10.1,13.5)$ & $9.3(8.0,10.9)$ & $9.7(8.2,11.5)$ & $10.2(9.3,11.2)$ \\
\hline & Smaller than average & 724 & 964 & 1019 & 2708 & $8.9(6.4,12.1)$ & $13.8(10.7,17.7)$ & $11.1(8.2,14.8)$ & $11.5(9.7,13.5)$ \\
\hline & Very small & 2071 & 2225 & 1619 & 5915 & $14.9(12.7,17.5)$ & $16.5(14.2,19.0)$ & $14.7(12.2,17.6)$ & $15.4(14.1,16.9)$ \\
\hline \multirow[t]{2}{*}{ Toilet type } & Unimproved & 9394 & 9271 & 9117 & 2898 & $12.7(11.5,14.1)$ & $12.2(11.1,13.5)$ & $11.3(10.1,12.7)$ & $9.6(8.0,11.5)$ \\
\hline & Improved & 546 & 1335 & 1018 & 27782 & $11.7(8.5,16.0)$ & $9.6(7.2,12.6)$ & $8.6(6.2,11.8)$ & $12.1(11.4,12.9)$ \\
\hline \multirow[t]{2}{*}{ Drinking water source } & Unimproved & 5683 & 4926 & 3182 & 16301 & $13.4(11.6,15.4)$ & $12.5(11.0,14.3)$ & $11.4(9.9,13.2)$ & $11.6(10.7,12.5)$ \\
\hline & Improved & 4255 & 5672 & 5692 & 13110 & $12.2(10.7,13.8)$ & $11.1(9.8,12.6)$ & $11.2(9.2,13.6)$ & $12.5(11.4,13.6)$ \\
\hline \multirow[t]{2}{*}{ Residence } & Urban & 724 & 1372 & 1108 & 3204 & $8.8(6.0,12.9)$ & $9.3(7.2,12.0)$ & $7.0(5.0,9.6)$ & $8.4(7.0,10.0)$ \\
\hline & Rural & 9247 & 9357 & 9087 & 27691 & $13.0(11.0,14.4)$ & $12.3(11.1,13.5)$ & $11.6(10.3,13.1)$ & $12.3(11.6,13.1)$ \\
\hline \multirow[t]{2}{*}{ Stunting } & Normal & 2217 & 6201 & 5987 & 14404 & $11.7(9.9,13.8)$ & $11.4(10.0,13.0)$ & $10.9(9.5,12.4)$ & $12.0(11.1,12.9)$ \\
\hline & Stunted & 2205 & 4388 & 3678 & 10272 & $13.8(11.8,16.1)$ & $12.4(11.0,13.8)$ & $12.0(10.2,14.0)$ & $11.7(10.7,12.8)$ \\
\hline \multirow[t]{2}{*}{ Underweighting } & Normal & 2217 & 7734 & 7368 & 17318 & $11.7(9.9,13.8)$ & $11.2(10.1,12.5)$ & $10.8(9.6,12.1)$ & $11.4(10.6,12.2)$ \\
\hline & Underweighted & 2205 & 2855 & 2327 & 7388 & $13.8(11.8,16.1)$ & $14.0(12.1,16.1)$ & $12.9(10.6,15.6)$ & $13.0(11.8,14.3)$ \\
\hline \multirow[t]{2}{*}{ Wasting } & Normal & 2217 & 9620 & 8710 & 20547 & $11.7(9.9,13.8)$ & $11.5(10.4,1.26)$ & $10.9(9.7,12.2)$ & $11.5(10.7,12.3)$ \\
\hline & Wasted & 2205 & 968 & 978 & 4151 & $13.8(11.8,16.1)$ & $16.8(13.7,20.4)$ & $14.8(11.3,19.1)$ & $13.6(12.0,15.3)$ \\
\hline \multirow{4}{*}{$\begin{array}{l}\text { Radio listening frequency } \\
\text { in the last week of survey }\end{array}$} & Not at all & 6486 & 5379 & 7549 & 19414 & $12.4(110,139)$ & $11.9(10.4,13.5)$ & $10.5(9.2,11.9)$ & $11.5(10.7,12.4)$ \\
\hline & Less than once a week & 2375 & 3439 & 1299 & 7113 & $13.6(11.4,161)$ & $11.7(9.8,13.9)$ & $12.3(9.5,15.8)$ & $12.4(11.1,13.9)$ \\
\hline & At least once a week & 305 & 1903 & 1347 & 3556 & $18.3(12.1,26.8)$ & $12.2(10.1,14.6)$ & $13.5(10.6,17.1)$ & $13.2(11.5,15.2)$ \\
\hline & Almost everyday & 805 & - & - & 805 & $10.4(7.5,14.4)$ & - & - & $10.4(7.5,14.4)$ \\
\hline \multirow{4}{*}{$\begin{array}{l}\text { Television watching } \\
\text { Frequency in the last } \\
\text { week of survey }\end{array}$} & Not at all & 9125 & 7910 & 8408 & 24742 & $12.9(11.6,14.4)$ & $12.6(11.2,14.1)$ & $11.1(9.8,12.6)$ & $12.2(11.4,13.1)$ \\
\hline & Less than once a week & 611 & 2595 & 966 & 4172 & $11.8(7.9,17.3)$ & $11.8(9.8,14.1)$ & $14.0(10.3,18.7)$ & $12.3(10.6,14.2)$ \\
\hline & At least once a week & 59 & 909 & 821 & 1789 & $9.7(3.3,25.0)$ & $6.9(4.6,10.1)$ & $7.9(5.5,11.1)$ & $7.4(5.7,9.5)$ \\
\hline & Almost everyday & 160 & - & - & 160 & $3.5(1.9,6.6)$ & - & - & $3.5(1.9,6.6)$ \\
\hline
\end{tabular}

Note: No education: those who did not attend school, Primary: those who completed grades 1-8, Secondary: those who completed grades 9-12, Higher: those with a college certificate, diploma, or above; Improved water: household's drinking water source is from protected spring, protected well, and piped water, Unimproved water source: household's drinking water source is from unprotected spring, unprotected well, tanker truck, surface water, irrigation channel, and cart with small truck; Improved toilet: pit latrine with slab; VIP, flush to septic tank, flush to sewer system, and flush to pit latrine compost; Unimproved toilet: pit latrine without slab, bucket latrine, hanging latrine, no-facility, or open field; occupation of mother and house head is based on EDHS category

The problem can be reduced by changing the country's community practices, mainly shifting to alternative energy sources, using an improved stove, and behavior change. These were indicated to be effective $[49,50]$. A prior study revealed improved stoves that effectively reduce the pollutants' emission in the country [51], although the use is low [52]. Therefore, effort on the wide-scale implementation of Climate Resilient Green Economy (CRGE) with the dissemination of improved stoves as one of the strategies remains essential to improve the coverage and use to minimize the problem [53].

\section{Strengths and limitations of the study}

This study's strengths include that it used nationally representative data with a representative sample size collected in three different periods and analyzed using multilevel modeling. However, it has the following limitations: the data were based on a cross-sectional study design. The variables like ARI and size of the children were based on the respondent's self-report, leading to bias.

\section{Conclusion}

More than $10 \%$ of children suffer from an acute respiratory infection, and about $98 \%$ of households used solid biomass fuel in the country. In the families where the food was cooked outdoor, there was a lower risk of having children with ARI than that cooked inside the house. There was an inclining trend in the number of households that cooked the food in the outdoor environments and a separate building. The multilevel modeling shows a variation in the infection of the disease among households of different surveys. But still, an effort remains mainly on awareness creation on cooking indoor homes of well-ventilated and shifting 
Table 3 Multilevel logistic regression on the association of food cooking places with ARI in under-five children in controlling other variables, EDHS, 2005-2016

\begin{tabular}{|c|c|c|c|c|}
\hline Variables & Category & $\begin{array}{l}\text { Model-I } \\
\text { OR(95\% Cl) }\end{array}$ & $\begin{array}{l}\text { Model-II } \\
\text { OR }(95 \% \mathrm{Cl})\end{array}$ & $\begin{array}{l}\text { Model-III } \\
\text { OR }(95 \% \mathrm{Cl})\end{array}$ \\
\hline \multirow[t]{5}{*}{ Child age } & 0 years & & & 1.00 \\
\hline & 1 years & & & $0.90(0.74,1.09)$ \\
\hline & 2 years & & & $0.73(0.60,0.88)$ \\
\hline & 3 years & & & $0.66(0.55,0.79)$ \\
\hline & 4 years & & & $0.48(0.39,0.59)$ \\
\hline \multirow[t]{5}{*}{ Child size } & Very large & & & 1.00 \\
\hline & Larger than average & & & $0.75(0.58,0.96)$ \\
\hline & Average & & & $0.73(0.60,0.89)$ \\
\hline & Smaller than average & & & $0.85(0.65,1.11)$ \\
\hline & Very small & & & $1.16(0.94,1.43)$ \\
\hline \multirow[t]{2}{*}{ Stunting } & Stunted & & & 1.00 \\
\hline & Normal & & & $1.13(0.94,1.35)$ \\
\hline \multirow[t]{2}{*}{ Underweighting } & Underweight & & & 1.00 \\
\hline & Normal & & & $0.77(0.61,0.98)$ \\
\hline \multirow[t]{2}{*}{ Wasting } & Wasted & & & 1.00 \\
\hline & Normal & & & $1.00(0.81,1.23)$ \\
\hline \multirow[t]{4}{*}{ Education of father } & No education & & & 1.00 \\
\hline & Primary & & & $1.10(0.92,1.31)$ \\
\hline & Secondary & & & $1.02(0.73,1.41)$ \\
\hline & Higher & & & $0.95(0.53,1.80)$ \\
\hline \multirow[t]{8}{*}{ Occupation of father } & Did not work & & & 1.00 \\
\hline & Professional & & & $0.64(0.36,1.13)$ \\
\hline & Sales & & & $0.84(0.51,1.38)$ \\
\hline & Agriculture & & & $0.92(0.59,1.44)$ \\
\hline & Services & & & $1.15(0.56,2.36)$ \\
\hline & Skilled & & & $0.89(0.48,1.53)$ \\
\hline & Unskilled & & & $1.00(0.50,1.59)$ \\
\hline & Other & & & $0.51(0.26,1.02)$ \\
\hline \multirow[t]{5}{*}{ Occupation of mother } & Did not work & & & 1.00 \\
\hline & Sales & & & $1.22(0.97,1.52)$ \\
\hline & Agriculture & & & $1.17(0.97,1.41)$ \\
\hline & Skilled & & & $1.00(0.71,1.41)$ \\
\hline & Other & & & $0.69(0.45,1.04)$ \\
\hline \multirow[t]{4}{*}{ Education of mother } & No education & & & 1.00 \\
\hline & Primary & & & $1.09(0.91,1.30)$ \\
\hline & Secondary & & & $0.98(0.62,1.56)$ \\
\hline & Higher & & & $1.42(0.67,3.00)$ \\
\hline \multirow[t]{5}{*}{ Quintile } & Poorest & & & 1.00 \\
\hline & Poorer & & & $0.93(0.73,1.19)$ \\
\hline & Middle & & & $0.96(0.74,1.23)$ \\
\hline & Higher & & & $0.98(0.76,1.25)$ \\
\hline & Highest & & & $0.75(0.56,1.01)$ \\
\hline Frequency of listening radio the last week & Not at all & & & 1.00 \\
\hline
\end{tabular}


Table 3 Multilevel logistic regression on the association of food cooking places with ARI in under-five children in controlling other variables, EDHS, 2005-2016 (Continued)

\begin{tabular}{|c|c|c|c|c|}
\hline Variables & Category & $\begin{array}{l}\text { Model-I } \\
\text { OR(95\% Cl) }\end{array}$ & $\begin{array}{l}\text { Model-II } \\
\text { OR }(95 \% \text { Cl) }\end{array}$ & $\begin{array}{l}\text { Model-III } \\
\text { OR }(95 \% \text { Cl) }\end{array}$ \\
\hline & Less than once a week & & & $1.23(1.01,1.50)$ \\
\hline & At least once a week & & & $1.50(1.19,1.88)$ \\
\hline & Almost everyday & & & $0.96(0.54,1.70)$ \\
\hline \multirow[t]{4}{*}{ Frequency of watching television in the last week of survey } & Not at all & & & 1.00 \\
\hline & Less than once a week & & & $0.84(0.67,1.06)$ \\
\hline & At least once a week & & & $0.59(0.38,0.93)$ \\
\hline & Almost everyday & & & $0.26(0.05,1.34)$ \\
\hline \multirow[t]{7}{*}{ Age of mother } & $15-19$ & & & 1.00 \\
\hline & $20-24$ & & & $0.94(0.62,1.41)$ \\
\hline & $25-29$ & & & $0.91(0.61,1.36)$ \\
\hline & $30-34$ & & & $0.96(0.64,1.44)$ \\
\hline & $35-39$ & & & $0.87(0.57,1.34)$ \\
\hline & $40-44$ & & & $1.07(0.65,1.78)$ \\
\hline & $44-49$ & & & $0.64(0.36,1.15)$ \\
\hline \multirow[t]{2}{*}{ Toilet type } & Unimproved & & & 1.00 \\
\hline & Improved & & & $0.96(0.71,1.29)$ \\
\hline \multirow[t]{2}{*}{ Drinking water source } & Unimproved & & & 1.00 \\
\hline & Improved & & & $1.02(0.86,1.21)$ \\
\hline \multirow[t]{2}{*}{ Residence } & Rural & & & 1.00 \\
\hline & Urban & & & $0.77(0.53,1.14)$ \\
\hline \multirow[t]{3}{*}{ Food cooking place } & Inside the house & & 1.00 & 1.00 \\
\hline & In separate building & & $0.86(0.75,0.99)$ & $0.81(0.69,0.96)$ \\
\hline & Outside the house & & $0.70(0.56,0.88)$ & $0.56(0.40,0.75)$ \\
\hline Random intercept for households within survey & & $0.13^{\mathrm{a}}$ & $0.10^{\mathrm{a}}$ & 0.003 \\
\hline Random intercept for survey & & $0.37^{\mathrm{a}}$ & $0.29^{\mathrm{a}}$ & $0.39^{\mathrm{a}}$ \\
\hline Random slope for place of cooking & & & $.08^{\mathrm{a}}$ & $0.11^{\mathrm{a}}$ \\
\hline
\end{tabular}

${ }^{a}$ The denotes the statistical significance of random intercept and slope

to alternative energy sources. Besides, promoting the use of improved stoves can affect reducing the problem in the country. This can be through the integration of health sectors, mainly health extension programs of the Ministry of Health, designed to deliver health services at the grass-root level, including healthy housing, and the Ministry of Water, Irrigation, and Energy providing alternative energy sources, mainly biogas and others.

\section{Abbreviations}

ARI: Acute respiratory infectionFEVForced expiratory volumeFVCForce vital capacityOROdds ratioDHSDemographic Health SurveyPM10Particulate matter

\section{Acknowledgements}

We would like to thank Measure DHS for providing the dataset to conduct this study. We also acknowledge Tara Wilfong (MD, MPH), University Orlando, Florida Area 64 connections, Global Health Consultant for USAID Feed the Future Innovation Lab for Livestock Systems, now a Fulbright Scholar in Ethiopia at Haramaya University for language edition.

\section{Authors' contributions}

AG, SG, YM, and TA conceived and designed the study, analyzed the data, and interpreted and drafted the manuscript. The authors have read and approved the final manuscript.

Funding

It is not applicable

\section{Availability of data and materials}

The datasets used and/or analyzed during the current study belong to DHS program. The authors can provide in discussion with the data owner

\section{Ethics approval}

We follow the principles and procedures of the data owner (Measure DHS Program). Each survey was conducted after the ethical clearance was obtained from the appropriate Ethics Review Committee of the country.

\section{Competing interests}

The authors declare that they have no competing interest.

\section{Author details}

${ }^{1}$ Department of Environmental Health, College of Health and Medical Sciences, Haramaya University, Dire Dawa, Ethiopia. ${ }^{2}$ School of Nursing and 
Midwifery, College of Health and Medical Sciences, Haramaya University, Dire Dawa, Ethiopia.

\section{Received: 13 July 2020 Accepted: 4 November 2020} Published online: 30 November 2020

\section{References}

1. Zar HJ, Ferkol TW. The global burden of respiratory disease-impact on child health. Pediatr Pulmonol. 2014:49(5):430-4.

2. UNICEF. The state of the world's children 2016: a fair chance for every child UNICEF. New York: United Nations Children's Fund; 2016.

3. WHO. World health statistics 2015. Geneva: World Health Organization; 2015.

4. Accinelli RA, Leon-Abarca JA, Gozal D. Ecological study on solid fuel use and pneumonia in young children: a worldwide association. Respirology. 2017;22(1):149-56.

5. Seidu A-A, Dickson KS, Ahinkorah BO, Amu H, EKM D, Kumi-Kyereme AJS-p. Prevalence and determinants of acute lower respiratory infections among children under-five years in sub-Saharan Africa: evidence from demographic and health surveys. SSM Popul Health. 2019;8:100443.

6. Janjua N, Mahmood B, Dharma V, Sathiakumar N, Khan MI. Use of biomass fuel and acute respiratory infections in rural Pakistan. Public Health. 2012; 126(10):855-62.

7. Lim SS, Vos T, Flaxman AD, Danaei G, Shibuya K, Adair-Rohani H, AlMazroa MA, Amann M, Anderson HR, Andrews KG. A comparative risk assessment of burden of disease and injury attributable to 67 risk factors and risk factor clusters in 21 regions, 1990-2010: a systematic analysis for the Global Burden of Disease Study 2010. Lancet. 2012;380(9859):2224-60.

8. Chafe ZA, Brauer M, Klimont Z, Van Dingenen R, Mehta S, Rao S, Riahi K, Dentener F, Smith KR. Household cooking with solid fuels contributes to ambient PM2. 5 air pollution and the burden of disease. Environ Health Perspect. 2014;122(12):1314-20

9. Perera FP. Multiple threats to child health from fossil fuel combustion: impacts of air pollution and climate change. Environ Health Perspect. 2016; 125(2):141-8.

10. Bartington S, Bakolis I, Devakumar D, Kurmi O, Gulliver J, Chaube G, Manandhar D, Saville N, Costello A, Osrin D. Patterns of domestic exposure to carbon monoxide and particulate matter in households using biomass fuel in Janakpur, Nepal. Environ Pollut. 2017;220:38-45.

11. Dasgupta S, Huq M, Khaliquzzaman M, Pandey K, Wheeler D. Who suffers from indoor air pollution? Evidence from Bangladesh. Health Policy Plan. 2006;21(6):444-58.

12. Gurley ES, Homaira N, Salje H, Ram PK, Haque R, Petri W, Bresee J, Moss WJ, Breysse P, Luby SP. Indoor exposure to particulate matter and the incidence of acute lower respiratory infections among children: a birth cohort study in urban Bangladesh. Indoor Air. 2013;23(5):379-86.

13. GEA: Global Energy Assessment - Toward a Sustainable Future, 2012, Cambridge University Press, Cambridge UK and New York, USA and the International Institute for Applied Systems Analysis, Laxenburg, Austria.

14. WHO. WHO guidelines for indoor air quality: household fuel combustion. Geneva: World Health Organization; 2014.

15. Sk R, Rasooly MH, Barua S. Do fuel type and place of cooking matter for acute respiratory infection among Afghan children? Evidence from the Afghanistan DHS 2015. J Biosoc Sci. 2020;52(1):140-53.

16. Bruce N, Pope D, Rehfuess E, Balakrishnan K, Adair-Rohani H, Dora C. WHO indoor air quality guidelines on household fuel combustion: strategy implications of new evidence on interventions and exposure-risk functions. Atmospheric Environ. 2015;106:451-7.

17. Buchner $H$, Rehfuess EA. Cooking and season as risk factors for acute lower respiratory infections in African children: a cross-sectional multi-country analysis. PloS one. 2015;10(6):e0128933.

18. Mondal D, Paul P. Effects of indoor pollution on acute respiratory infections among under-five children in India: evidence from a nationally representative population-based study. PLOS ONE. 2020;15(8):e0237611.

19. Ethiopian Public Health Institute (EPHI) [Ethiopia] and ICF. Ethiopia Mini Demographic and Health Survey 2019: key indicators. Rockville: EPHI and ICF; 2019.

20. Dagne H, Andualem Z, Dagnew B, Taddese AA. Acute respiratory infection and its associated factors among children under-five years attending pediatrics ward at University of Gondar Comprehensive Specialized Hospital,
Northwest Ethiopia: institution-based cross-sectional study. BMC Pediatr. 2020;20(1):1-7.

21. Alemayehu S, Kidanu K, Kahsay T, Kassa M. Risk factors of acute respiratory infections among under five children attending public hospitals in southern Tigray, Ethiopia, 2016/2017. BMC Pediatr. 2019;19(1):380.

22. Sanbata H, Asfaw A, Kumie A. Association of biomass fuel use with acute respiratory infections among under-five children in a slum urban of Addis Ababa, Ethiopia. BMC Public Health. 2014;14(1):1122.

23. Abuka T. Prevalence of pneumonia and factors associated among children 2-59 months old in Wondo Genet district, Sidama zone, SNNPR, Ethiopia. Curr Pediatr Res. 2017:7.

24. Geberetsadik A, Worku A, Berhane Y. Factors associated with acute respiratory infection in children under the age of 5 years: evidence from the 2011 Ethiopia demographic and health survey. Pediatric Health Med Ther. 2015;6:9.

25. Anteneh ZA, Hassen HY. Determinants of acute respiratory infection among children in Ethiopia: a multilevel analysis from Ethiopian Demographic and Health Survey. Int J Gen Med. 2020;13:17.

26. CSA, Macro-ORC. Demographic and health survey 2005. Addis Ababa, Ethiopia and Calverton: Central Statistical Agency and ORC Macro; 2006.

27. Central Statistical Agency [Ethiopia] and ICF International: Ethiopia Demographic and Health Survey [https://dhsprogram.com/pubs/pdf/fr255/fr255.pdf]. Accessed 20 Aug 2018.

28. Central Statistical Agency [Ethiopia] and ICF International [https://dhsprogram. com/pubs/pdf/FR328/FR328.pdf]. Accessed 14 May 2018.

29. World Population Review 340 S Lemon Ave Walnut, Ethiopia Population 2020 [http://worldpopulationreview.com/countries/ethiopia-population/]. Accessed 14 May 2018.

30. Children in Ethiopia, the situation of children in Ethiopia [https://www. unicef.org/ethiopia/children-ethiopia]. Accessed 20 June 2020.

31. Central Statistical Agency - CSA/Ethiopia, ICF. Ethiopia Demographic and Health Survey 2016. Addis Ababa: CSA and ICF; 2017.

32. Singh A, Singh MN. Diarrhoea and acute respiratory infections among under-five children in slums: Evidence from India. Peer-reviewed J. 2014:33.

33. Dadi AF, Kebede Y, Birhanu Z. Determinants of pneumonia in children aged two months to five years in urban areas of Oromia Zone, Amhara Region, Ethiopia. Open Access Lib J. 2014;1(08):1.

34. Rana J, Uddin J, Peltier R, Oulhote YJEE. Associations between Indoor air pollution and acute respiratory infections among under-five children in Afghanistan: do socioeconomic status and sex matter? Int J Environ Res Public Health. 2019;3:323-4.

35. Khalequzzaman M, Kamijima M, Sakai K, Chowdhury N, Hamajima N, Nakajima T. Abstract. Indoor Air. 2007;17(4):297-304.

36. Amsalu ET, Akalu TY, Gelaye KA. Spatial distribution and determinants of acute respiratory infection among under-five children in Ethiopia: Ethiopian Demographic Health Survey 2016. PloS one. 2019;14(4):e0215572.

37. De Onis M, Onyango AW, Borghi E, Garza C, Yang H, Group WMGRS. Comparison of the World Health Organization $(\mathrm{WHO})$ child growth standards and the National Center for Health Statistics/WHO international growth reference: implications for child health programmes. Public Health Nutr. 2006;9(7):942-7.

38. Gelman A, Hill J. Data analysis using regression and multilevel/hierarchical models. New York: Cambridge university press; 2006.

39. Goldstein H. Multilevel statistical models, vol. 922. London: Wiley; 2011.

40. Admasie A, Kumie A, Worku A, Tsehayu W. Household fine particulate matter (PM 2.5) concentrations from cooking fuels: the case in an urban setting, Wolaita Sodo, Ethiopia. Air Qual Atmosphere Health. 2019;12(6):755-63.

41. Langbein JJPO. Firewood, smoke and respiratory diseases in developing countries—the neglected role of outdoor cooking. PLoS One. 2017;12(6):e0178631.

42. Kilabuko JH, Nakai S. Effects of cooking fuels on acute respiratory infections in children in Tanzania. Int J Environ Res Public Health. 2007;4(4):283-8.

43. Adesanya OA, Chiao C. A multilevel analysis of lifestyle variations in symptoms of acute respiratory infection among young children under five in Nigeria. BMC Public Health. 2016;16(1):880.

44. Yohannes AZ. The benefits of the use of biogas energy in rural areas in Ethiopia: a case study from the Amhara National Regional State, Fogera District. African J Environ Sci Technol. 2015;9(4):332-45.

45. Mengistu M, Simane B, Eshete $G$, Workneh T. A review on biogas technology and its contributions to sustainable rural livelihood in Ethiopia. Renew Sustain Energy Rev. 2015;48:306-16.

46. Guta D. Assessment of biomass fuel resource potential and utilization in Ethiopia: sourcing strategies for renewable energies. Int J Renew Energy Res. 2012;2(1):131-9. 
47. Tasew W, Abayneh H. Practices and challeges of domestic biogas technology use: The Case of, Wondogenet District and Hawassa City Administration, Sidama Zone, Southern Ethiopia, Ethiopia. J Resourc Dev Manag. 2017;37:7-17.

48. Ethiopia-the health extension program in Ethiopia. Universal Health Coverage (UNICO) studies series; no. 10 [http://hdl.handle.net/10986/13280]. Accessed 12 May 2018.

49. Lamichhane P, Sharma A, Mahal A. Impact of cleaner fuel use and improved stoves on acute respiratory infections: evidence from India. Int Health. 2017; 9(6):349-66

50. Yu F. Indoor air pollution and children's health: net benefits from stove and behavioral interventions in rural China. Environ Resource Econ. 2011;50(4): 495-514.

51. Mamuye F, Lemma B, Woldeamanuel T. Emissions and fuel use performance of two improved stoves and determinants of their adoption in Dodola, southeastern Ethiopia. Sustain Environ Res. 2018;28(1):32-8.

52. Adane MM, Alene GD, Mereta ST, Wanyonyi KL. Facilitators and barriers to improved cookstove adoption: a community-based cross-sectional study in Northwest Ethiopia. Environ Health Prev Med. 2020;25:1-12.

53. Ethiopia's Climate Resilient Green Economy (CRGE): Green Economy Strategy. [https://www.greengrowthknowledge.org/national-documents/ ethiopia\%E2\%80\%99s-climate-resilient-green-economy-green-economystrategy]. Accessed 18 Sept 2020

\section{Publisher's Note}

Springer Nature remains neutral with regard to jurisdictional claims in published maps and institutional affiliations.

Ready to submit your research? Choose BMC and benefit from:

- fast, convenient online submission

- thorough peer review by experienced researchers in your field

- rapid publication on acceptance

- support for research data, including large and complex data types

- gold Open Access which fosters wider collaboration and increased citations

- maximum visibility for your research: over $100 \mathrm{M}$ website views per year

At BMC, research is always in progress.

Learn more biomedcentral.com/submissions 